\title{
The Association Between Serum Malondialdehyde and Nitric Oxide Level of Children Living in Area of Chronic Pesticide Exposure
}

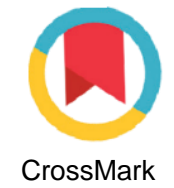

\author{
Astra Parahita $^{1 \star}$, Galuh Hardaningsih ${ }^{1}$, Anindita Soetadji ${ }^{1}$
}

Department of Pediatrics, Faculty of Medicine, Diponegoro University, Indonesia

Keywords:

Malondialdehhyde

Nitric oxide

Oxidative stress

Pesticides

*) Correspondence to: astraprahita@gmail.com

Article history:

Received 26-05-2020

Accepted $06-06-2020$

Availableonline 01-07-2020

\begin{abstract}
Background: Chronic exposure of organophosphate pesticides is oxidative stress that causes liver and aortic damage. Malondialdehyde (MDA) is a biological marker of oxidative damage to cell lipids membrane. The liver produces insulin growth factor-1 (IGF-1) which stimulates the enzyme nitric oxide synthase (eNOS) to produce vascular nitric oxide (NO). Children who are living in those areas may be exposed to pesticide chronically.

Objective: The study aims is to determine the relationship between serum MDA and NO level of children living in an area of chronic pesticide exposure.

Methods: Cross-sectional study was conducted to 50 children aged between 8-10 years in agriculture areas of Brebes. Serum MDA and NO level was measured at the same time using ELISA method, data were shown on a numerical scale. Statistical analysis by Pearson correlation.

Results: Fifty children met the criteria, consisting of 30 males $(60 \%)$ and 20 females $(40 \%)$. The mean of serum MDA level in males, females, and total subjects were normal $6.03(3.86) \mu \mathrm{g} / \mathrm{mL}, 5.18(2.11) \mu \mathrm{g} / \mathrm{mL}$, and $5.69(2.60) \mu \mathrm{g} / \mathrm{mL}$, respectively. The mean of serum NO level in males, females, and total subjects were increased $79.42(50.78) \mu \mathrm{mol} / \mathrm{L}, 68.11(50.81) \mu \mathrm{mol} / \mathrm{L}$, and $74.90(50.58) \mu \mathrm{mol} / \mathrm{L}$, respectively. There was no association between serum MDA and NO level found. Conclusion: Serum NO level of children living in an area of chronic pesticide exposure was higher than normal value. However, there was no association between serum MDA and NO level found.
\end{abstract}

DIMJ, 2020, 1(1), 10-15 DOI: https:// doi.org/10.14710/dimj.v1i1.7897

\section{Introduction}

Pesticides are toxic chemical compounds used to control agricultural pest organisms. $\frac{1}{}$ Pesticides enter the body as free radicals which cause oxidative stress and increase cell membrane lipid peroxidation. $\underline{2}, \underline{3}$ Malondialdehyde, a biological marker for oxidative stress in the blood, is the primary outcome of the reaction between free radicals and cell membrane phospholipids. ${ }^{4}$ The rate of pesticide use in Brebes Regency is one of the highest in Southeast Asia, using the insecticide chlorpyrifos organophosphates and fungicides of the mancozab group. $\frac{5}{}$ Agricultural societies, including children, in the Brebes Regency are at highest risk of exposure to pesticides., .4

The organs which suffer damage due to chronic exposure to organophosphates are liver and aorta. The liver produces insulin growth factor-1 (IGF-1) which is circulating in the serum works to stimulate the enzyme nitric oxide synthase (eNOS) to synthesis nitric oxide (NO). NO is an endothelium-derived relaxing factor (EDRF) that plays a role in modulating vascular tone by stimulating vascular dilation, inhibiting platelet function, preventing platelet aggregation, and decreasing the proliferation of tunica intima cells, thus preventing the occurrence of arteriosclerosis. $\underline{6}$. 
A study on children aged 6-12 years in Brazil's tobacco farming areas indicates an increase in oxidative stress markers. $\stackrel{8}{ }$ Arteriosclerosis does not generally occur in childhood, but research in Ecuadorian agricultural areas has shown that arterial between the levels of serum MDA and NO in children living in areas with chronic exposure to pesticides.

\section{Methods}

This is an observational analytic study with a cross-sectional design. It was conducted on 50 children aged $8-10$ years in shallot farming areas of Brebes. The inclusion criteria of this study are children aged $8-10$ years, living in shallot farming areas for more than one year, willing and permitted by their parents to participate in the study. Whereas for the exclusion criteria, they are obesity/malnutrition, children with chronic inflammatory conditions, such as diabetes mellitus, metabolic syndrome, congenital heart disease, thalassemia, asthma, history of hypoxic-ischemic encephalopathy, and children with severe infections or illnesses. According to sample size calculation, there were 50 subjects recruited in the study. The levels of serum MDA and NO were measured with the ELISA method and the data are displayed on the numerical scale. Anthropometric measurements were obtained using the Seca 874 scale and the Seca 213 stadiometer. They were interpreted using the $W H O$ anthroplus version 3.2.2 software. Statistical analysis was done with the Pearson correlation using SPSS for windows 21.0. This study has received ethical clearance approval from the Medical Research Ethics Commission of the Faculty of Medicine, Diponegoro
University/ dr. Kariadi Hospital, Semarang No. 26/ EC/ FK-RSDK/ 2017 and each subject have been given written permission from their parents

\section{Results}

A correlation study with a cross-sectional design was carried out in the Brebes Regency in January 2017 on children aged 8-10 years living in chronic pesticide exposure areas. This study was conducted on children living in shallot farming areas for at least one year. Fifty children met the inclusion criteria with normal subject baseline data distribution. The overall characteristics of the study subjects are displayed in Table 1.

Table 1. Baseline characteristics of the subjects

\begin{tabular}{cc}
\hline \multicolumn{1}{c}{ Variable } & $\begin{array}{c}\text { Subject } \\
(\mathbf{n = 5 0})\end{array}$ \\
\hline Gender, n (\%) & $30(60)$ \\
Male & $20(40)$ \\
Female & \\
Age (years) & $9.24(0.69)$ \\
Mean (SB) & $8-10$ \\
Min-max & \\
HAZ (SD) & $-1.59(0.92)$ \\
Mean (SB) & $-3.96-(+0.40)$ \\
Min-max & \\
BMI (SB) & $-0.39(0.99)$ \\
Mean (SB) & $-2.48-(+1.99)$ \\
Min-max & \\
\hline
\end{tabular}

The difference in serum MDA based on gender, $\mathrm{HAZ}$, and BMI were analyzed using independent $\mathrm{t}$ test. The results of serum MDA levels are shown in Table 2.

Table 2. Serum MDA levels among the subjects

\begin{tabular}{lccc}
\hline \multirow{2}{*}{ Variable } & \multicolumn{2}{c}{ MDA $(\boldsymbol{\mu g} / \mathbf{m L})$} & \multirow{2}{*}{$\boldsymbol{p}$} \\
\cline { 2 - 3 } & Mean $(\mathrm{SD})$ & Min-max & \\
\hline Total subjects $(\mathrm{n}=50)$ & $5.69(2.60)$ & $2.15-14.65$ & \\
Gender & & & 0.26 \\
$\quad$ Male $(\mathrm{n}=30)$ & $6.03(3.86)$ & $2.39-14.64$ & \\
$\quad$ Female $(\mathrm{n}=20)$ & $5.18(2.11)$ & $2.15-10.21$ & \\
HAZ & & & \multirow{2}{*}{0.12} \\
$\quad$ Short stature $(\mathrm{n}=14)$ & $6.62(3.57)$ & $3.22-14.65$ & \\
$\quad$ Normal stature $(\mathrm{n}=36)$ & $5.33(2.05)$ & $2.15-11.89$ & \\
BMI & & & \\
$\quad$ Malnourished $(\mathrm{n}=2)$ & $6.33(0.73)$ & $5.82-6.85$ & \\
$\quad$ Well-nourished $(\mathrm{n}=48)$ & $5.67(2.65)$ & $2.15-14.65$ & \\
\hline
\end{tabular}


T-test analysis also performed to find the difference of NO level based on gender, HAZ, and BMI. The results of serum NO levels are shown in Table 3.

Table 3. Serum NO level among the subjects

\begin{tabular}{|c|c|c|c|}
\hline \multirow{2}{*}{ Variable } & \multicolumn{2}{|c|}{ NO $(\mu \mathrm{mol} / \mathrm{L})$} & \multirow{2}{*}{$\boldsymbol{P}$} \\
\hline & Mean (SD) & $\operatorname{Min}-\max$ & \\
\hline Total subjects $(\mathrm{n}=50)$ & $74.90(50.58)$ & $3.73-196.63$ & \\
\hline Gender & & & 0.44 \\
\hline Male $(\mathrm{n}=30)$ & $79.42(50.78)$ & $4.16-196.63$ & \\
\hline Female $(\mathrm{n}=20)$ & $68.11(50.81)$ & $7.73-194.34$ & \\
\hline HAZ & & & 0.22 \\
\hline Short stature $(\mathrm{n}=14)$ & $60.62(44.92)$ & $4.16-188.1$ & \\
\hline Normal stature $(\mathrm{n}=36)$ & $80.45(52.15)$ & $43.73-196.63$ & \\
\hline \multicolumn{4}{|l|}{ BMI } \\
\hline Malnourished $(\mathrm{n}=2)$ & $155.01(46.86)$ & $121.87-188.14$ & \\
\hline Well-nourished $(n=48)$ & $71.56(48.34)$ & $3.73-196.63$ & \\
\hline
\end{tabular}

MDA and NO levels were distributed normally. Therefore, the correlation test was done using Pearson correlation. The association between serum MDA and NO levels is shown in Table 4.

Table 4. The association between serum MDA level and serum NO level among the subjects

\begin{tabular}{cllllll}
\hline \multirow{2}{*}{ Variable } & \multicolumn{2}{c}{$\begin{array}{c}\text { Male } \\
(\mathbf{n = 3 0})\end{array}$} & \multicolumn{2}{c}{$\begin{array}{c}\text { Female } \\
(\mathbf{n = 2 0})\end{array}$} & \multicolumn{2}{c}{$\begin{array}{c}\text { Total subject }(\mathbf{n} \\
\mathbf{=} \mathbf{5 0})\end{array}$} \\
\cline { 2 - 8 } & $\mathbf{r}$ & $\boldsymbol{p}$ & $\mathbf{r}$ & $\boldsymbol{p}$ & $\mathbf{r}$ & $\boldsymbol{p}$ \\
\hline MDA and NO & -0.26 & 0.89 & -0.006 & 0.981 & -0.001 & 0.994 \\
\hline
\end{tabular}

\section{Discussion}

Brebes Regency is the largest shallot farming centre in Indonesia, with one of the largest pesticide, primarily chlorpyrifos organophosphate insecticides and mancozab fungicides, use in Southeast Asia. ${ }^{2-4}$ Children living in farming areas of Brebes are at the highest risk of exposure to pesticides. ${ }^{1}$ A study by Arcury et al. has indicated that pesticide exposure can occur directly when children are playing and helping around the paddy fields or indirectly from pesticide residues carried on their parents' clothing and tools after returning from farming. ${ }^{11}$ Chronic pesticide exposure in areas with high intensity of pesticide use can lead to oxidative stress. ${ }^{12,13}$

This study was conducted on subjects aged 8 10 years with a more significant proportion of male subjects compared to their female counterparts, at 30 $(60 \%)$ and $20(40 \%)$ respectively. Results of the anthropometric measurements showed that the children suffering short stature and underweight (HAZ was between $-3.96 \mathrm{SD}$ and $+0.40 \mathrm{SD}$, and BMI for age was between $-2.48 \mathrm{SD}$ and +1.99 SD. Subjects aged $8-10$ years were selected with consideration to previous studies in Brazil and Ecuador which reported arterial stiffness due to chronic pesticide exposure in children aged $6-12$ years. ${ }^{8,14}$ Previous studies have been conducted on children in areas of chronic pesticide exposure. Adgate et al. have measured metabolite markers for pesticide exposure, including MDA, from children in areas exposed to pesticides, but there was no assessment on the effects of pesticide exposure on organs, such as NO which is a marker of hepatic and aortic damage. ${ }^{15}$ A study on the effect of pesticide exposure was done by Eskenazi et al. by examining the association between intrauterine exposure to pesticides, one of which is measuring MDA levels, on the neural development of babies. ${ }^{14}$

The results of this study indicate that the serum MDA levels are still within normal limits based on the reference value of $3.76-11.19 \mu \mathrm{g} / \mathrm{mL} .^{16}$ Nascimento $\mathrm{SN}$ et al. studied 40 children aged 6-12 years living in Brazilian tobacco plantation areas. The tobacco cultivation cycle consists of seeding preparations (June), planting (August), harvest (November - December) and storage (January May). Pesticides are sprayed in the seeding preparation and planting stages. MDA was measured in 2 periods, in June at the beginning of pesticide use and in December at the end of the harvest. The results obtained were that MDA levels in the first period were higher than the second period $(9,46$ (SB 0.42) vs $7.72(\mathrm{SB} 0.33) \mu \mathrm{mol} / \mathrm{L}, p<0.01) .{ }^{8}$ This study differed from Nascimento et al.'s study where only one MDA measurement was performed and time of 
sampling was not determined based on the start of spraying, planting, or harvesting.

This study has shown that the male MDA levels were higher than the female, however, this is not statistically significant (6.03 (SB 2.86) vs 5.18 (SB 2.11) $\mu \mathrm{g} / \mathrm{mL}, p=0.26$ ). A study by Arcury et al found that pesticide metabolite levels, one of which was MDA, was significantly higher in male children compared to female children (4.46 (SB 0.31) vs 3.59 (SB 0.27), $p=0.035) .{ }^{11}$ Other studies by Kilic E et al and Dragonjic LP et al. showed no difference in normal MDA levels of male children compared to female children. ${ }^{17,18}$

The mean level of NO in the study subjects was higher than the normal reference value obtained from a study by Ghasemi et al. in healthy children, both for male and female, and for the total, which is $13.6-$ $69.2 \mu \mathrm{mol} / \mathrm{L}, 11.4-66.0 \mu \mathrm{mol} / \mathrm{L}$ and $12.2-69.4$ $\mu \mathrm{mol} / \mathrm{L}$ respectively. ${ }^{19}$ This study has found that the level of NO in male children is higher than female children, however, this is not statistically significant (79.42 (SB 50.78) vs 68.11 (SB 50.81) $\mu \mathrm{mol} / \mathrm{L}, p=$ 0.44 ). Other studies have shown that high levels of NO are also found in conditions such as HIE, thalassemia, sickle cell disease and amoebiasis enteritis. ${ }^{20-23}$ A cohort study was conducted by Correia-Costa L et al on 313 obese children. They found that the level of biological markers for oxidative stress and NO increased in relation to fat accumulation, as well as an association between increased oxidative stress and increased levels of NO. ${ }^{24}$ A study by Sweeten et al. have indicated that the level of NO among children with autism is higher than the level among healthy children. This is related to the high level of interferon- $\gamma$ (IFN- $\gamma$ ), which is one of the biological signs of inflammation. ${ }^{25}$ The subjects in this study had good general conditions, they were not obese, nor did they have any history of HIE. Hematologic examinations such as haemoglobin levels, peripheral blood profiles, lipid profiles and other inflammatory markers were not performed in this study.

Several studies have also proven the association between NO levels and nutritional status. Perampalli et al. studied oxidative stress in children aged $1-5$ years. The study was conducted by assessing serum NO and other signs of oxidative stress in 45 malnourished children and 30 healthy children as controls. NO was higher in the malnourished group. ${ }^{26}$ A study by Engelen on NO production in children with cystic fibrosis compared serum NO in 17 healthy children, nine children with cystic fibrosis without malnutrition, and seven children with cystic fibrosis and malnutrition. They concluded that the highest
NO production was found among children with both cystic fibrosis and malnutrition. ${ }^{27}$ The results of this study showed a higher mean level of NO among children with malnutrition which was 2.17 times higher than the children without malnutrition (155.01 (SB 46.86) vs 71.56 (SB 48.34) $\mu \mathrm{mol} / \mathrm{L})$. The subjects of this study were mostly well-nourished, there were 2 children who suffered undernutrition, and none suffered malnutrition. Therefore, it could not be established whether malnutrition was associated with high levels of NO in this study. Further research with equal proportions of subjects still needs to be done to prove an association between malnutrition and levels of serum NO among children in areas of chronic pesticide exposure.

Franc PC et al. conducted a cross-sectional study on 110 children and found that children with oxidative stress in the form of obesity have higher concentrations of NO and MDA compared to healthy controls, however their study did not assess the association between NO and MDA. ${ }^{28}$ Noshy MM et al. compared 51 workers in Egypt who were exposed to carbamate or organophosphate pesticides for more than five years from their work with a mean exposure time of 9.8 (SB 3.5) years to 50 controls who were exposed not from their work. The results of the study showed that the MDA outcomes of the working group were higher than the control group (6.51 (SB 1.95) vs 2.344 (SB 8.823) nmol/mL). ${ }^{10}$ Unlike the studies mentioned above, the results of this study did not indicate any association between the level of serum MDA and NO in children living in areas of chronic pesticide exposure ( $p=0.994)$.

A limitation of this study is the small number of subjects, which is close to the minimal number of subjects. The cause of increased NO levels in this study cannot be ascertained. Several other factors which may affect levels of serum MDA and NO, such as anemia and inflammation, have not been entirely excluded.

\section{Conclusion}

The mean level of serum NO in children living in areas of chronic pesticide exposure is higher than the normal values. There is no association between MDA level and NO level in the blood of children living in areas of chronic pesticide exposure.

\section{References}

1. Council on Environtmental Health. Pesticide exposure in children. Pediatrics. 2012; 130: e1757-63. 
2. Apriyanto C, Hermini S, Sulistiowati. Kebijakan pemerintah daerah kabupaten brebes dalam pemberdayaan petani bawang merah. 2013.

3. Litbang Depkes. Pencemaran bahan agrokimia perlu diwaspasai. 2010.

4. Suhartono. Pesticide exposure as risk factor thyroid dysfunction (Study on childbearing age woman in Brebes District). Dissertation. Diponegoro University. 2010.

5. Rasipin. Laporan Dinas Kesehatan Brebes. 2011.

6. Kinlay S, Creager MA, Fukumoto M, Hikita H, Fang JC, Selwyn AP, et al. Endothelium-derived nitric oxide regulates arterial elasticity in human arteries in vivo. Hypertension. 2001; 38: 104953.

7. Yildrim E, Baydan E, Kanbur M, Kul O, Çinar $\mathrm{M}$, Ekici H, Atmaca N. The effect of chlorpyrifos on isolated thoracic aorta in rats. Biomed Res Int. 2013; 1-7.

8. Nascimento SN, Göethel G, Baierle M, Barth A, Brucker N, Charão MF, et al. Environmental exposure and effects on health of children from a tobacco-producing region. Environ Sci Pollut Res. 2016: 1-15.

9. Grandjean P, Harari R, Barr DB, Debes F. Pesticide exposure and stunting as independent predictors of neurobehavioral deficits in Ecuadorian school children. Pediatrics. 2006; 117 (3): e546-56.

10. Noshy MM, Hussein AS, Shahy EM, ElShorbagy HM, Taha MM, Abdel-Shafy EA. Assessment of anticholinesterase toxicity, oxidative stress and antioxidant status in carbamate and organophosphorus pesticidesexposed agricultural workers. International Journal of Pharmaceutical and Clinical Research. 2017; 9 (3): 205-9.

11. Arcury TA, Grzywacz JG, Barr DB, Tapia J, Chen H, Quandt SA. Pesticide urinary metabolite levels of children in eastern North Carolina farmworker households. Environmental Health Perspectives. 2007; 115 (7): 1255-60.

12. Andersen HR, Grandjean P. Potential developmental neurotoxicity of pesticides used in Europe. Environmental Health. 2008; 7 (50): 50.

13. Bernard Weiss B, Amler S, Amler RW. Pesticides. Pediatrics. 2004; 113 (4): 1030-6.

14. Eskenazi B, Marks AR, Bradman A, Harley K, Barr DB, Johnson C, et al. Organophosphate pesticide exposure and neurodevelopment in young Mexican-American children. Environ Health Perspect. 2007; 115: 792-8.
15. Adgate JL, Barr DB, Clayton CA, Eberly LE, Freeman NC, Lioy PJ, et al. Measurement of children's exposure to pesticides: analysis of urinary metabolite levels in a probability-based sample. Environmental Health Perspectives. 2001; 109 (6): 583-9.

16. Ramaekers V, Bosman B, Jansen G, Wanders R. Increased plasma malondialdehyde associated with cerebellar structural defects. Arch Dis Child. 1997; 77 (3): 231-4.

17. Dragonjic LP, Jovanovic M, Vrbic M, Konstantinovic L, Kostic V, Dragonjic I. Antioxidant defense and oxidative stress in children with acute hepatitis A. Ann Saudi Med. 2011; 31 (3): 258-62.

18. Kilic E, Yazar S, Saraymen R, Ozbilge H. Serum malondialdehyde level in patients infected with Ascaris lumbricoides. World J Gastroenterol. 2003; 9(10): 2332-4.

19. Ghasemi A, Zahediasi S, Azizi F. Reference values for serum nitric oxide metabolites in pediatrics. Nitiric oxide. 2010; 23: 264-268.

20. Kumar A, Mittal R, Khanna D. Free radical injury and blood-brain barrier permeability in hypoxic-ischemic encephalopathy. Pediatrics. 2008; 122 (3).

21. Naithani R, Chandra J, Verma P, Narayan S. Peroxidative stress and antioxidant enzymes in children with $\beta$-thalassemia major. Pediatric blood and cancer. 2006; 47 (7): 780-5.

22. Namıduru ES, Tarakçıŏglu M, Namıduru M, Kocabaş R, Erbağc1 B, Meram I. Increased serum nitric oxide and malondialdehyde levels in patients with acute intestinal amebiasis. Asian Pac J Trop Biomed. 2011; 1 (6): 478-81.

23. Radhakrishnan DK, Bendiak GN, Corral DM, Al-Saleh S, Bhattacharjee R, Allen MK, et al. Lower airway nitric oxide is increased in children with sickle cell disease. J Pediatr. 2012; 160: 937.

24. Correia-Costa L, Sousa T, Morato M, Cosme D, Afonso J, Areias JC, et al. Oxidative stress and nitric oxide are increased in obese children and correlate with cardiometabolic risk and renal function. British Journal of Nutrition. 2016; 116: 805-15.

25. Sweeten TL, Posey DJ, Shankar S, McDougle CJ. High nitric oxide production in autistic disorder: a possible role for interferon- $\gamma$. Biological Psychiatry. 2004; 55 (4): 434-37.

26. Perampalli T, Swami SC, Kumbar KM, Suryakar AN, Shaikh AK. Possible role of oxidative stress in malnourished children. Curr Pediatr Res. 2010; 14 (1): 19-23. 
27. Engelen MP, Com G, Luiking YC, Deutz NE. Stimulated nitric oxide production and arginine deficiency in children with cystic fibrosis with nutritional failure. J Pediatr. 2013; 163: 369-75.

28. Franc PC, Alonso ST, Estal RM, Vericat JM. Nitric oxide production in increased in severely obese children relates to markers of oxidative stress and inflammation. J atherosclerosis. 2011; 215 (2): 475-80. 